Milica Gvozdenović ${ }^{1, *}$, Enis Džunuzović ${ }^{1}$, Branimir Jugović2 ${ }^{2}$ Branimir Grgur ${ }^{1}$

${ }^{1}$ University of Belgrade, Faculty of Technology of Metallurgy, Belgrade, Serbia, ${ }^{2}$ Institute of Technical Sciences Serbian

Academy of Science and Arts, Belgrade, Serbia
Review paper

ISSN 0351-9465, E-ISSN 2466-2585

UDC:520.197.6

doi: $10.5937 / Z a s M a t 1802282 \mathrm{G}$

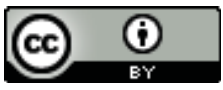

Zastita Materijala 59 (2)

282 - 292 (2018)

\title{
Polyaniline based corrosion inhibitors for conventional organic coatings
}

\begin{abstract}
Corrosion protection using conventional coatings is the most used method. Application of polyaniline (PANI) as an inhibitor in conventional coating is based on its proven and well examined protective nature, with motivation for replacement of hazardous materials used as inhibitors. Experimental procedures for investigation of the influence of PANI in coatings are focused both on evaluation of physical properties of the coatings studied by FTIR, Raman and UV spectroscopy, thermogravimetric analysis, SEM and TEM microcopies, while the protective nature of the coating, applied at the first place on steel, is studied by accelerated corrosion testing using humidity and salt chamber, electrochemical impedance spectroscopy and polarization measurements upon immersion in corrosion media.
\end{abstract}

Key words: polyaniline, inhibitors, epoxy coatings, alkyd coatings.

\section{INTRODUCTION}

The uniqueness of intrinsically conducting polymers (ICPS) is based both on their polymeric nature and their conductivity permitting them to be a topic of numerous theoretical and practical researches. At the very beginning of the research in the field it was shown that, apart from the request of the existence of conjugated double bonds, doping of the polymeric chain is necessary condition for macroscopic electrical conductivities [1-3]. The doping of ICPS, although as a term taken from semiconductors terminology, refers to a different procedure by which stoichiometric amount of doping ions is introduced to the polymer by oxidation or rarely by reduction [3-5]. This large quantity of dopant ions in ICP polymer structure is responsible for novel properties such as: dopant amount dependant electrical conductivity, reversible electrochemistry based on doping/dedoping process, optical activity, magnetic properties, corrosion protection ability etc. [1,6-8].

*Corresponding author- Milica Gvozdenović

E-mail: popovic@tmf.bg.ac.rs

Paper received: 26. 04. 2018.

Paper accepted: 13. 05. 2018.

Paper is available on the website:

www.idk.org.rs/journal
These unique features are widely considered in broad field of applications including electrochemical energy storage and conversion [9,10], magnetic shielding [11,7-18], biosensors and sensors $[14,16,17]$, electronic devices $[18,19]$ and corrosion protection [20-30].

Up to date, numerous ICPS were synthesized and characterized, but not surprisingly polyaniline (PANI) is the most investigated. Unlike any other ICP, PANI, exist in different oxidation forms depending on $\mathrm{pH}$ and applied potential [31,32], of which only PANI in the form of half-oxidized emeraldine salt (ES) is electrically conductive. On the other hand, mechanism of PANI conductivity is also different based on the fact that nitrogen, originated from amino group, is involved in conjugated double bond system and also in the formation of radical cation, meaning that electrical conductivity is affected by the oxidation and protonation levels as well $[8,33]$.

PANI, similar to other ICPs can be synthesized chemically and electrochemically following the mechanism of oxidative radical polymerization $[34,35]$. Although both procedures has its advantages, chemical synthesis is more likely to be used in practical applications, since large quantities of the polymer can be obtained. On the other hand, electrochemical synthesis offers route without using oxidizing agents owing to direct deposition 
onto electrode achieved by applying anodic current or potential. Electrochemical synthesis of PANI is easily performed on inert electrodes, but in the case of active materials and alloys, high values of the potentials indispensable for initiation of the polymerization leads to intensive metal dissolution or formation of nonconductive passive or pseudopassive layers impeding polymerization. Nevertheless, lot of efforts were given in order to find suitable electrolyte in which PANI can be obtained electrochemically on active metals [21,22,29,36-40].

Efficiency of PANI in the field of corrosion protection is evident and well documented. The research if based on investigation of individual coatings of PANI $[21,29,38]$ and coating systems in which PANI is used either as a primer coating obtained chemically or electrochemically $[27,28]$ or as a powder component in commercial alkyd [26,40,41-49], epoxy [21,30,50-57], polyurethane or other organic coatings [40,58-60].

The conventional approach to corrosion protection relays on application of coating systems in which PANI and other ICPs can be used as promising alternative to hexavalent chromium or lead inhibitors [26,40,41,46-549,61]. In such systems PANI is used in the form of chemically obtained powders, although we have recently used electrochemically obtained PANI powders as corrosion inhibitors in commercial alkyd coatings [26]. Moreover, composites of PANI and especially inorganic pigments usually present in conventional coatings were also considered, exhibiting increase of the mechanical and protective properties $[40,47,54,57,62]$.

Having in mind the practical importance of corrosion control, this paper aims to shortly review literature dedicated to application of PANI based inhibitors in conventional organic coatings such are epoxy and alkyd.

\section{POLIANILNE}

Although the eldest known ICP dating for over a century ago when "anilne blacks" were used for coloring cotton [4], the intense research of this unique polymer is related to discovery of the conductivity of emeraldine salt (ES) form of PANI [63].

\subsection{Polianiline oxidation forms}

As stated earlier, PANI depending on conditions, may exist in various oxidation states according to schematic representation given in Fig.1 [4].

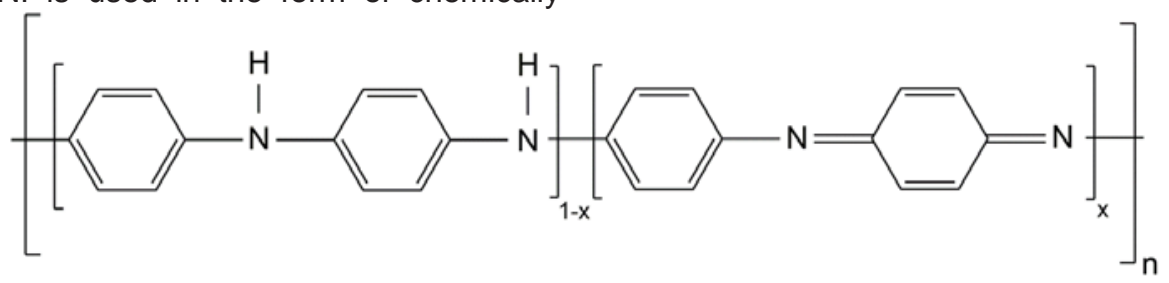

Fig.1. Schematic representation of PANI oxidation states

Slika 1. Šematski prikaz oksidacionih stanja PANI

Fully reduced form is leucoemerladine base, LB $(x=0)$, fully oxidized form is perningraniline base $P B,(x=1)$, while half reduced state refers to emeraldine base EB $(x=0.5)$. None of these forms is conductive, the only conductive form is ES that is protonated or doped form of EB. The existence of various forms of PANI is dependent on $\mathrm{pH}$ and electrode potential, and all of the mentioned forms can be mutually converted chemically or electrochemically according to scheme in Fig.2. $[31,32]$. The knowledge on electrochemical conversion between PANI forms is of special importance in understanding the mechanism of corrosion protection

In the optimal conditions of both chemical and electrochemical synthesis, PANI is obtained in the form of conductive ES. Electrochemical reactions of ES are of particular importance for interpreting and studying the role of PANI in corrosion protection. ES upon oxidation is transformed to the completely oxidized form of dark blue perningraniline salt (PS) which when treated by alkali transforms to violet PB. On the other hand, reduction of $E S$ leads to transparent $L B$, ES can be also transformed in reaction with alkali to blue EB [32]. Relaying on PANI redox activity, with relative electrode potential in the range of 0,6 to $1,0 \mathrm{~V}$ (vs. $\mathrm{SHE}$, at $\mathrm{pH} 7$ ) [64] that is grater then relative potentials of metals and alloys to be protected, and grater then that of chromate couple it is reasonable to explain such great interest for PANI in the field of corrosion protection. 


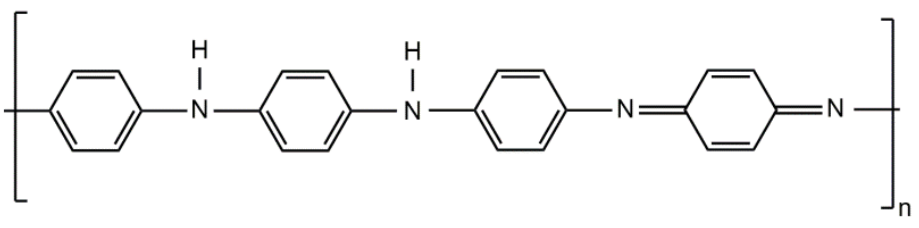

$$
\left.\begin{array}{l}
+2 e \\
-2 A^{-}
\end{array}\right\rfloor \uparrow \begin{aligned}
& -2 e \\
& +2 A^{-}
\end{aligned}
$$

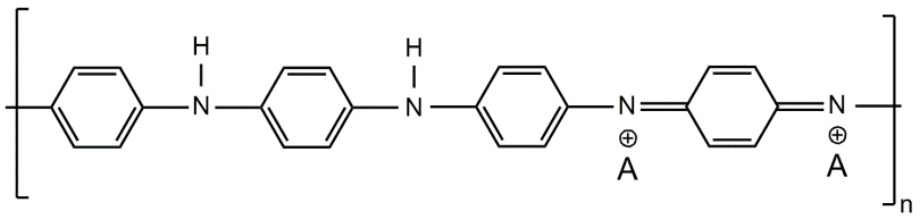

$$
\begin{aligned}
& +2 e \\
& -2 A^{-}
\end{aligned} \downarrow \uparrow \begin{aligned}
& -2 e \\
& +2 A^{-}
\end{aligned}
$$

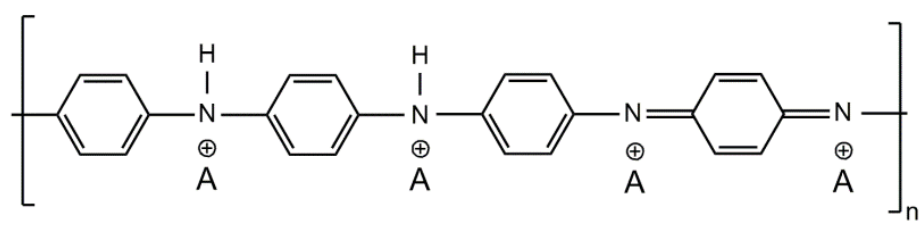

Figure 2. Schematic representation of electrochemical conversion of ES

Slika 2. Šema elektrohemijskih reakcija ES

\subsection{Polianiline synthesis}

PANI to be used as an inhibitor in conventional organic coatings is commonly obtained by chemical synthesis. The mechanism of chemical synthesis of PANI is well studied and refers to oxidative radical polymerization. First step is formation of anilinium cation radical by oxidation of aniline monomer, this reaction requires strong acidic environment since
$\mathrm{pH}>2$, leads to formation of different oligomeric forms $[31,65]$.

The next step refers to formation of dimers by coupling of cation radicals followed by the loss of protons (deprotonation) and rearomatization. Lately, the dimers are oxidized to form dimer radical cations reacting with other cation radicals leading to chain propagation $[31,65,66]$. After the oxidant is completely consumed, aniline in solution reduces PS to form ES as seen in Fig.3. [73].

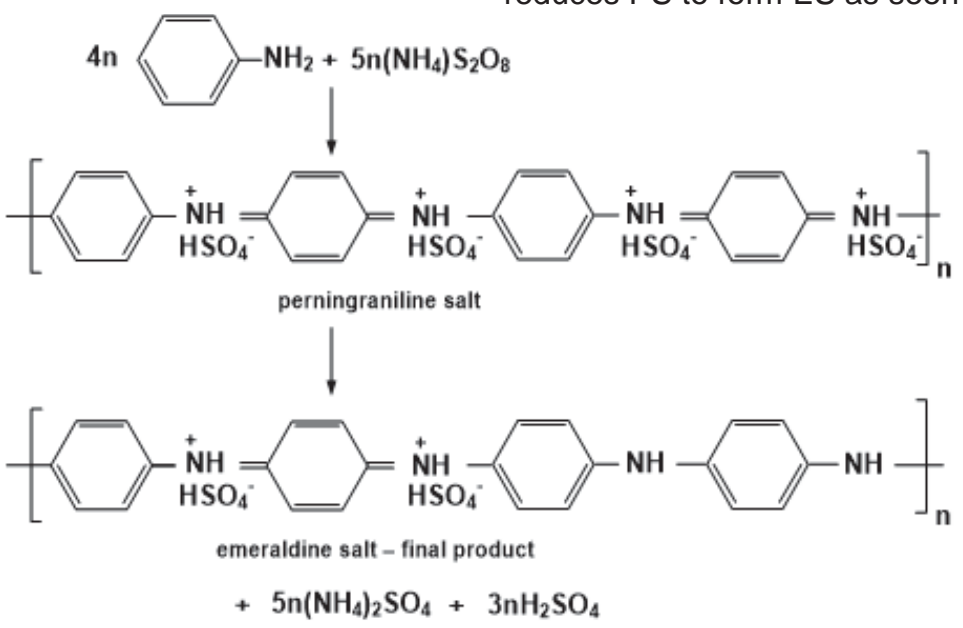

Figure 3. Chemical synthesis of PANI using $(\mathrm{NH})_{4} \mathrm{~S}_{2} \mathrm{O}_{8}$ Slika 3. Hemijska sinteza PANI korišćenjem $(\mathrm{NH})_{4} \mathrm{~S}_{2} \mathrm{O}_{8}$ 
The most widely used chemical oxidant (redox initiator) $(\mathrm{NH})_{4} \mathrm{~S}_{2} \mathrm{O}_{8}$, but other oxidants are such as: $\mathrm{FeCl}_{3}, \mathrm{Ce}\left(\mathrm{SO}_{4}\right)_{2}, \mathrm{H}_{2} \mathrm{O}_{2}, \mathrm{KMnO}_{4}$ etc. were reported as well [67].

\section{COATINGS CONTAINING POLYANILINE}

Metals and their alloys used in industrial constructions, in most of the aggressive environments, are thermodynamically unstable and therefore prone to corrosion. The conventional approach for minimizing the materials loss is application of organic coatings. Depending on corrosion environment and type of the material to be protected different coatings systems are used. Generally, the composition of an anticorrosion coating refers to a binder, pigments, solvent (diluent) and different additives (driers, thickeners, surface active agents, anti-settling additives etc.) [68]. Coatings are commonly classified by type of its binder to epoxy, alkyd, polyurethane, polyester, vinyl, rubber etc.

Coating system include primer and top coat but in thicker system may also contain intermediate or body coats. Primers contains usually inorganic compounds as corrosion inhibitors, while topcoats contain color pigments and extenders with a role to improve barrier performances and to protect the coating from UV light damage $[40,69]$.

Certainly the most effective inhibitor is zinc chromate and lead compounds which are starting to be less employed nowadays for environmental end health concerns. Other inorganic inhibitors such is zinc phosphate, is also effective, but it was recently denoted as being harmful to aquatic environment [49]. Therefore a request for an effective corrosion inhibitor promoted application of ICP at the first place PANI, as an environmentally friendly corrosion inhibitor.

\subsection{Epoxy coatings}

Epoxy coatings poses good mechanical properties, chemical resistance in various aggressive corrosion environments including acidic electrolytes also superior resistance to alkali then most of other coatings, good susceptibility to UV light degradation and finally excellent adhesion to metallic substrate [69].

Armelin et al. examined the effect of addition of PANI in the state of ES and polypyrrole (PPY) to corrosion performance of epoxy paint coating based on diglycidyl ether of bisphenol $A$ and polyamide on steel [55]. They performed accelerated immersion test and analyzed data according to procedure given in ASTM D1654-79 standard. The tests were performed on coated steel panels coated with deliberately introduced hole. Various experimental techniques were used in order to evaluate corrosion performances, including infrared spectroscopy, thermogravimetric analysis, immersion in $3.5 \% \mathrm{NaCl}$, optical microscopy and visual observation. It was concluded that addition of PANI ES and PPY to epoxy had not exhibited influence on FTIR spectra, neither on thermal behavior, but had influenced increase in corrosion protective ability. The paints with low amount of PANI ES of only 0.3 wt.\% showed the best results and they concluded that PANI can be used both as an inhibitor and also as an adhesion promoter [56].

In other article, Armelin et al. made a comparison of different ICP inhibitors in conventional epoxy coatings addid to a small amount of only $0.3 \mathrm{wt} . \%$ [42]. They used PANI-ES et PPY composite with carbon black and poly(3,4ethylenedioxythiophene) doped with poly(styrene sulphonate). According to results of FTIR, Raman spectroscopy and thermogravimetric analysis, no changes were observed by introducing additives to epoxy coatings in such low amount. On the other hand, such low amounts of ICP were sufficient to increase corrosion performances of epoxy paints, confirmed by accelerated corrosion assays in an aggressive media. It was shown that the protection against corrosion by epoxy modified by the addition of poly(3,4-ethylenedioxythiophene) doped with poly(styrene sulphonate), PANI-ES and especially, PANI-EB was remarkably higher than that of unmodified epoxy paint. On contrary, introducing of carbon black decreased the corrosion efficiency of the coating [42].

Radhakrishnan et al. used low doped PANI in epoxy powder coating deposited on steel by electrostatic spray coating [70]. The amount of PANI ranged between 1 and 7 wt. \%. Corrosion behavior was studied using exposure to hot saline electrolyte, salt spray test, while electrochemical impedance spectroscopy and Tafel curves were recorded upon immersion in $3.5 \% \mathrm{NaCl}$. The specimens were scratched in order to evaluate the possibility of self-healing [71]. All of the coatings shown no signs of corrosion after more than $1000 \mathrm{~h}$ of exposure to hot saline. On the other hand, the polarization experiments confirmed practically no changes in the appearance of the Tafel plots while corrosion current densities remain low comparing to simple without addition of PANI. The open circuit potential of all simples were stabile during $800 \mathrm{~h}$ of exposure to hot saline with average value of around $200 \mathrm{mV}$, while the open circuit potential of scratched simples with addition of PANI firstly dropped cathodically to the value of the bare steel of $-600 \mathrm{mV}$, while during prolonged exposure tended to rise into anodic region, which authors explained by the self-healing effect promoted by the presence of low dopped PANI in epoxy coating. They concluded that the low doped PANI which was used in their procedure in non-acidic route had captured aggressive $\mathrm{Cl}^{-}$ion by the doping of 
remained undopped sites, which promoted corrosion resistance [70].

Ge et al. used different amount of PANI in the form of ES, as an additives to epoxy raisin on steel in order to evaluate the enhancement if corrosion properties [56]. PANI nanofibers were obtained by direct oxidation mixed method at ambient temperature and doped with different inorganic acids: $\mathrm{HCl}, \mathrm{H}_{3} \mathrm{PO}_{4}, \mathrm{HNO}_{3}$ and $\mathrm{H}_{2} \mathrm{SO}_{4}$. Field emission-scanning electron microscopy reviled clear influence of different inorganic acids on morphology of PANI nanofibers. PANI ES obtained by doping with $\mathrm{H}_{2} \mathrm{SO}_{4}$ showed the best morphology with uniform diameter and several microns length of nanofibers, while UV and IR spectroscopy experiment shown no remarkable differences between PANI doped with different acids [56]. Based on the best morphology of $\mathrm{H}_{2} \mathrm{SO}_{4}$ doped PANI, Authors also studied the effect of amount of $\mathrm{H}_{2} \mathrm{SO}_{4}$ doped PANI ranging between $0 \%$ and $4 \%$ on the curing time of epoxy resin, after the content of PANI exceeded $1 \%$ the curing time increased significantly. Corrosion studies were performed using electrochemical impedance spectroscopy (EIS) and polarization measurements. EIS analysis indicated that the best improvement of corrosion protection had been obtained with $0.6 \%$. Morphology and dopant anion type also influenced corrosion performance with the best results obtained for $\mathrm{H}_{3} \mathrm{PO}_{4}$ doped PANI following by $\mathrm{H}_{2} \mathrm{SO}_{4}, \mathrm{HNO}_{3}$ and $\mathrm{HCl}$ doped PANI [56].

Baldissera and Ferreira examined addition of different forms of PANI, namely: emeraldine base-
EB, emeraldine salt-ES and sufonated PANI to epoxy paint and compared results to epoxy paints containing conventional inhibitors: zinc chromate and zinc phosphate [71]. For evaluation of corrosion protection ability of mentioned forms of PANI they performed electrochemical impedance spectroscopy experiments in $3 \% \mathrm{NaCl}$, and used optical micrographs before and after immersion in corrosion media to analyze appearance of the coatings after being subjected to corrosion. They concluded that all of the examined PANI forms wan added to epoxy resin were able to provide better corrosion protection to mild steel than epoxy coating alone. Sulfonated PANI was shown to provide the best results even better than commercial pigments [71].

Mostafaei and Nasirpouri investigated synthesis, characterization and corrosion behavior of epoxy coatings with addition of organic-inorganic hybrid nanocomposite of PANI and $\mathrm{ZnO}$, for corrosion protection of carbon steel [57]. They used chemical oxidative polymerization of aniline in the presence of camphor- sulfonic acid and $\mathrm{ZnO}$ nanorods. The obtained composites were analyzed by X-ray diffraction and Fourier transform infrared spectroscopy, scanning electron and transmission microscopies, thermogravimetric analysis and conductivity measurements [57]. Corrosion behavior of epoxy coatings with addition of PANIZnO nanocomposites on carbon steel was studied upon immersion in $3.5 \% \mathrm{NaCl}$ using electrochemical impedance spectroscopy and chronopotentiometry at open circuit potential (OCP) [57].
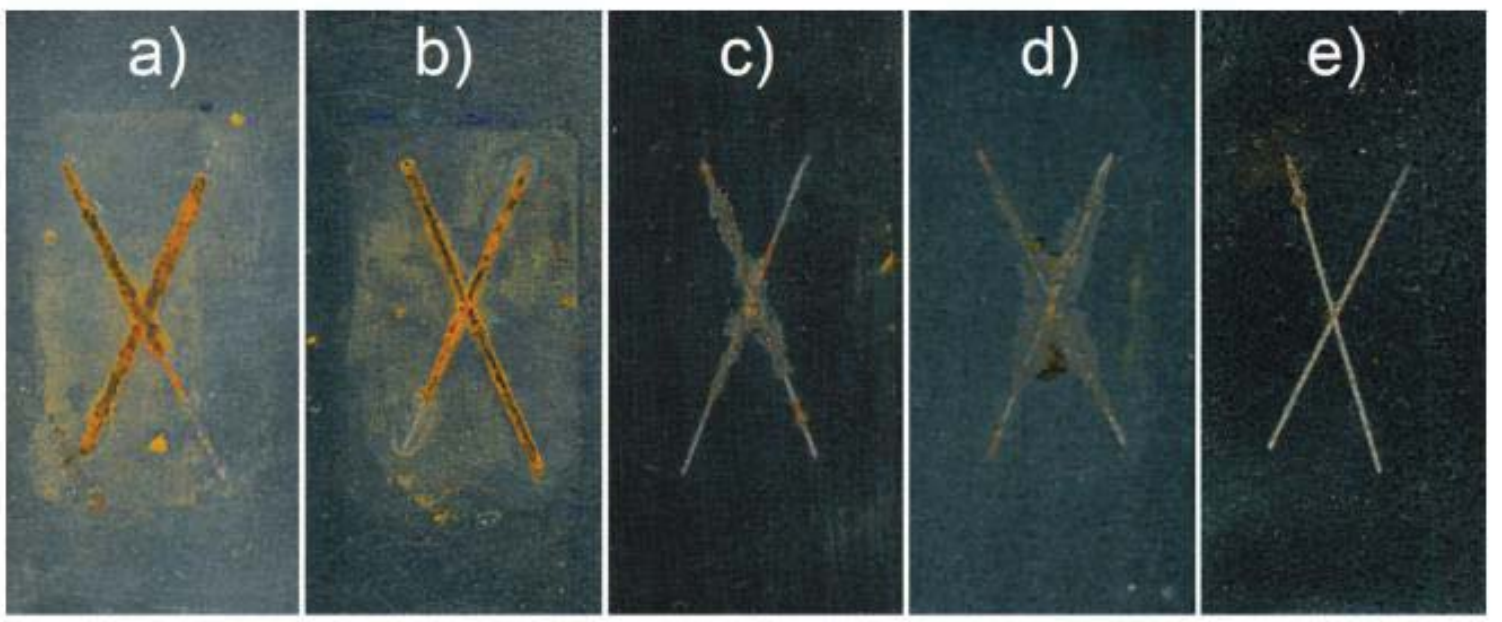

Figure 4. Photographs of the mild steel test panels coated with a) epoxy coating and epoxy coating b) 1 wt.\% of PANI, c) 2 wt.\% of PANI, d) 1 wt.\% of P-T-B6 and e) 2 wt.\% of P-T-B6 powder are mixed, after $200 \mathrm{~h}$ of immersion in 3\% $\mathrm{NaCl}$.

Slika 4. Fotografije test panela od mekog čelika sa: a) epoksidnom prevlakom b) epoksidnom prevlakom

sa dodatkom 1 mas.\% PANI b) epoksidnom prevlakom sa dodatkom 2 mas.\% PANI, c) epoksidnom prevlakom sa dodatkom 1 mas.\% of P-T-B6 i e) epoksidnom prevlakom sa dodatkom 2 mas. \% of P-T-B6 nakon 200 h u 3\% NaCl. (Reprintovano sa dozvolom (c) Elasvier 2015 iz reference 30.) 
They referred higher corrosion resistance and better barrier properties of epoxy coating with PANI-ZnO nanocomposites compared to both unmodified epoxy and epoxy/PANI coatings, while the OCP was shifted to the noble region due to presence of PANI pigments [57]. They also claimed that ability of passivation of the substrate in the presence of PANI was increased. The best results were obtained for epoxy coating with addition of PANI-ZnO nanocomposites. They explained they observation by the fact that the presence of $\mathrm{ZnO}$ nanorods in the composite significantly improved the barrier and corrosion efficiency of the epoxy coating owing to the flaky shaped structure of the PANI-ZnO nanocomposites [57].

Recently, we have performed systematic study on novel epoxy based nanocomposites containing $\mathrm{TiO}_{2}$-PANI core-shell nanocomposite synthesized by in situ oxidative polymerization of aniline in the presence of $\mathrm{TiO}_{2}$ nanoparticles surface previously modified with vitamin B6 [30]. To our knowledge vitamin $\mathrm{B} 6$ was first used in order to modify $\mathrm{TiO}_{2}$ aimed to decrease its agglomeration which is the basic problem for its practical application in coating formulations. We have used FTIR spectroscopy and UV spectroscopy to confirm surface modification by vitamin $\mathrm{B} 6$, while transmission electron microscopy confirmed core-shell structure of $\mathrm{TiO}_{2}$-PANI nanocomposite. We also examined the influence of PANI and $\mathrm{TiO}_{2}$-PANI core-shell nanocomposite on glass transition temperature, dielectric and dynamic mechanical properties. Corrosion protection properties of mild steel panels coated with epoxy coating, epoxy coating with PANI and epoxy coating with $\mathrm{TiO}_{2}$-PANI $\mathrm{B} 6$ modified core shell nanocoposite after $200 \mathrm{~h}$ of immersion in $3 \% \mathrm{NCl}$ are presented in Fig.4.

\subsection{Reprinted with permission of $@$ Elasvier 2015 , from ref. 30.}

The enhancement of the protective nature of the epoxy coating containing nanocomposite is evident, practically there was no signs of corrosion after $200 \mathrm{~h}$ of immersion in $3 \% \mathrm{NaCl}$. Such enhancement of the protection ability was explained by better miscibility of PANI due to the nanostructurization, with formation of PANI shell around $\mathrm{TiO}_{2}$ core that is responsible for the formation of uniform passive layer on steel. Based on results of dielectric measurements, better protection was also expected due to the lower permeability of the corrosion agents, thanks to hydrophobicity of the modified core shell composite that is in direct relation [72] with the increase of barrier properties of the modified epoxy coating [30].

Lin et al. reported epoxy coating formulation with addition of poly(stirenesulfonate)-PANI/ reduced graphene oxide (PSS-PANI/rGO) composite filler and examined their mechanic and anticorrosion properties of carbon steel coated with epoxy coating continuing this composite [72]. They reported the increase of both tensile strength and tensile toughness by $39 \%$ and $127 \%$, respectively of the epoxy by containing only 0.5 wt.\% of PSS$\mathrm{PANI} / \mathrm{rGO}$ comparing to epoxy alone. This observation was explained by strong interfacial bonding upon curing through the interaction between the PANI and epoxy. Corrosion studies of carbon steel coated with epoxy continuing PSS$\mathrm{PANI} / \mathrm{rGO}$ composite were performed by potentiodynamic polarization after $24 \mathrm{~h}$ of immersion in $5 \% \mathrm{NaCl}$ and revealed improved anticorrosion performance compared to those with the neat epoxy and epoxy/rGO coatings. The enhancement of anticorrosion fetures was explained by larger tortuosity of diffusion pathways, improved interfacial strength between the epoxy and the filler, and the passivation of the steel in the presence of PANI [72].

\subsection{Alkyd coatings}

Application of alkyd based coating is widely spread. The reason is a low price and ease of preparation, since they are one-component paint cured at the air. Both solvent and waterborne alkyd are commercially available [69]. However alkyd coatings have some disadvantages, firstly they continuously react with oxygen, even after curing, which is a reason of aging and secondly they are not useful in alkali conditions [69]. On the other hand, alkyd coatings poses relatively low barrier properties, therefore a choice of additives is very important issue [69]. The most used inhibitor in classical alkyd coating is zinc phosphate [48], which was recently reported to be toxic to aquatic environment and unhealthy to humans [48]. Therefore application of replacement of zinc compounds in alkyd coating by ICP at the first PANI is very perspective ground.

Gonalves et al. reported investigation aimed to compare performances of alkyd paints with doped PANI to those with zinc chromate [48]. They also attempted to evaluate the influence of the dopant type on performances of these coatings [48].

They used PANI EB and PANI doped with $\mathrm{HCl}$, p-toluenesulfonic acid, dodecylbenzenesulfonic acid and or camphorsulfonic acid. They also studied PANI derivates, namely, poly(omethoxyaniline) and poly(o - ethoxyaniline) both doped with $p$-toluenesulfonic acid [48]. They used FTIR and Raman spectroscopies and thermogravimetric analysis in order to characterized obtained paints, from which they came out of conclusion that there were no degradation of the alkyd paint upon mixing with 
polymers. From cyclic voltammetry experiments they observed electrochemical activity of alkyd coating with addition of both PANI and its derivate. They also performed corrosion studies using salt and humidity chambers which demonstrated grate increase in the protective ability of all coatings applied to carbon steel. The results were also verified by electrochemical impedance spectroscopy which showed that, after the first $24 \mathrm{~h}$ of immersion in $0.1 \mathrm{M} \mathrm{HCl}$ some of the coatings had capacitance values of the same order of magnitude as those of protective oxides. Those samples, both the resistance and capacitance remained stable after 15 days of immersion [48]. Raman spectroscopy taken after humidity chamber exposure revealed the existence of an oxide layer at the coating/substrate interface, composed of $\mathrm{Fe}_{2} \mathrm{O} 3$ and $\mathrm{Fe}_{3} \mathrm{O} 4$ in some of the [48] samples that which supported the mechanism of the formation of a protective oxide layer in the presence of additives based on ICPS.

Alam et al. examined several mechanical parameters such as: dry to touch and dry to hard times, stretch hardness, impact resistances, gloss, flexibility and conductivity of alkyd coatings with addition of PANI nanoparticles in the range of 0.5 to $2.5 \%$ [46]. PANI for these purposes was obtained by emulsion polymerization. Most of the examined properties specially starch hardness, enhanced comparing to alkyd alone, with increase of amount of PANI. The observed increase of the scratch hardness values was attributed to the improvement in the adhesion between PANI and metal substrate with higher loadings of PANI [46]. They performed salt spray test and recorded open circuit potentials in $\mathrm{HCl}$. They observed an initial shift towards positive potentials that increased with the increase of the amount of PANI in alkyd coating, indicating formation of a passive oxide layer. They proposed that the presence of PANI in the coating promoted oxidation of the ferrous ions to form a stable passive iron oxide film at the pin hole regions after a few days of immersion [46].

In other work Alam et. al. performed practically the same study but they used nano structured PANI / ferrite composite for alkyd coatings [47]. They explained the enhanced protective properties by maintaining the high resistance to corrosive ions owing to the presence of a dense, nonporous, continuous network structure [47]

Martí et al investigated different formulations of commercial alkyd coatings with $10 \mathrm{wt} \%$ of zinc phosphate which was subsequently replaced by addition of low amounts of PANI ES, PANI EB and partly oxidized polythiophene derivate [49]. They performed accelerated corrosion tests of steel panels coated with mentioned alkyd formulations in in $3.5 \% \mathrm{NaCl} 3.5$ at $\mathrm{pH} 6.6$ and $3 \% \mathrm{NaHSO}_{3}$ at $\mathrm{pH}$ 3.5 during $480 \mathrm{~h}$. The results were analyzed according to standards ASTM D714, ASTM D1654, UNE- EN-ISO 4624 which refers to: evaluation degree of blistering, degree of corroded surface and adhesion from pull-off test respectively. They also used electrochemical impedance spectroscopy upon immersion in $3.5 \% \mathrm{NaCl}$. For characterization of paints they used FTIR and thermogravimetric analysis. Among all of the investigated formulations, the one containing polythiophene exhibited the best adherence and the highest corrosion resistance which was explained by the fact that the miscibility of the polythiophene derivative with the alkyd formulation is the best among all used formulation [49].

In addition to this, both accelerated corrosion test and electrochemical impedance spectroscopy measurements revealed that the corrosion resistance of the formulation containing polythiophene was several orders of magnitude higher than that observed conventional alkyd formulation with zinc phosphate. It was revealed that polythiophene derivative induced the formation of a passivating and highly adhered layer preventing the access of corrosion agents to the metal substrate.

Bhanvase and Sonawane studied anticorrosive and mechanical properties of alkyd coatings with addition of $\mathrm{CaCO}_{3}$-PANI nanocomposite [45]. They used ultrasound assisted emulsion polymerization in order to obtained nanocomposite, with different amount of $\mathrm{CaCO}_{3}$ ranging from 1 to $8 \%$ of aniline monomer. Using XRD and TEM authors concluded that water repellent nano $\mathrm{CaCO}_{3}$ was thoroughly dispersed in PANI matrix. They performed crosscut adhesion, impact resistance test and gloss at 45 test according to ASTM standards. They observed that presence of $\mathrm{CaCO}_{3}-\mathrm{PANI}$ nanocomposite in alkyd coating resulted in better adhesion to the mild steel substrate. The cross-cut adhesion increased when loading of composite increased from $1 \%$ to $5 \%$.

Due to addition of $4 \% \mathrm{CaCO}_{3}$ in PANI matrix, there was a gain in impact strength. The enhancement in impact strength is because of presence of nano-size polymer matrix and $\mathrm{CaCO} 3$. The corrosion studies also revealed the increase in performances of alkyd coatings on steel upon addition of $\mathrm{CaCO}_{3}$-PANI nanocomposite, reflected in 30 times lowering of the corrosion current densities comparing to conventional alkyd coatings and the ennoblement of the open circuit potential upon immersion in $5 \% \mathrm{NaCl}$ [45].

Recently, we studied corrosion protection of alkyd paints with addition of different PANI based powders [26]. We used PANI powders obtained by 
different procedures both electrochemical and chemical while we used doping/dedoping in order to obtained EB and ES obtained by doping with benzoic acid. PANI powder was obtained electrochemically following procedure of galvanostatic synthesis on graphite electrode from aqueous electrolyte containing aniline and $\mathrm{HCl}$ [73], such powder was dedoped chemically using $\mathrm{NH}_{4} \mathrm{OH}$ and labeled as PANI obtained electrochemically in the form of EB as EBEC, EBEC was then doped with benzoic acid and labeled as EBES. We also obtained chemically
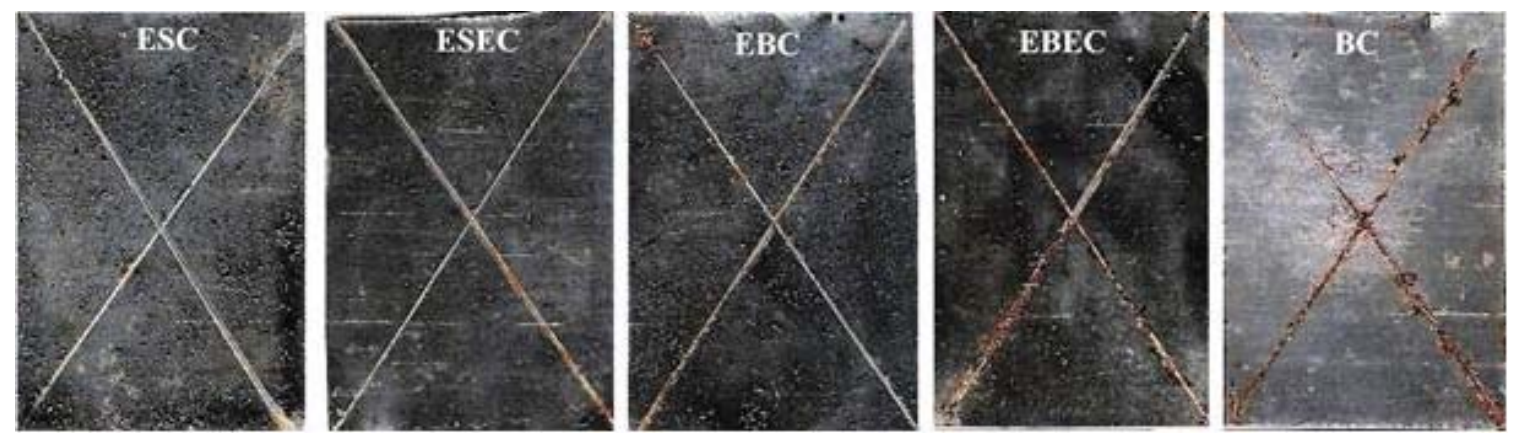

Figure 5. Comparison of the samples $(4 \mathrm{~cm} \times 6 \mathrm{~cm})$ after treatment in a humid chamber for 5 days. Reprinted with permission of (C) Elasvier 2013, from ref. 24

Slika 5. Poređenje izgleda uzoraka $(4 \mathrm{~cm} \times 6 \mathrm{~cm}$ ) nakon izlaganja vlažnoj komori u trajanju od 5 dana. (Reprintovano sa dozvolom (c) Elasvier 2011 iz reference 24.)

It is evident that corrosion protection efficiency followed the trend: ESC $>$ EBC $\sim$ ESEC $>$ EBEC $>$ $\mathrm{BC}$. This trend was attributed to differences in preparation procedure. Namely chemically formed PANI ES had less oligomeric forms as it was confirmed by UV spectroscopy. Practically the same trend is obtained by electrochemical impedance spectroscopy measurements during immersion in 3\% $\mathrm{NaCl}$. Since the best results were obtained with chemically synthetized ES in order to optimize the composition of alkyd coating different amounts of ESC were used between 1 and 10 wt. \% and corrosion studies were again performed using electrochemical impedance spectroscopy and electrical equivalent circuit was proposed and analyzed [26]. The optimal amount of ECS was 5 wt.\%, while it was concluded that PANI in the form of ES prevented the penetration of corrosive agents to the mild steel, acting as an active barrier protection enabling protection during more than 2 weeks.

\section{CONCLUSIONS}

Among numerous ICPS, PANI is the most studied from the corrosion protection purposes, not surprisingly for the reason that PANI can be easily obtained from low cost monomer while both chemical and electrochemical polymerization is possible. At the beginning of the research in the field of corrosion protection, PANI was applied as individual coating obtained either chemically or electrochemically. Having in mind practical importance of coating systems attention was given to use of PANI as an inhibitor in conventional organic coatings especially epoxy or alkyd. The idea for application of PANI as an inhibitor is a replacement of environmentally unaccepted inhibitors, such as zinc chromate, recently zinc phosphate and lead compounds. The corrosion studies revealed high efficiency of PANI in coating systems. Recently efforts were given in order to applied inhibitors based on PANI and inorganic materials with special attention given to nanostructured ones, which exhibited even better performances. By review of rich literature, it can be concluded that PANI is still an important material for application in the field of corrosion protection.

\section{REFERENCES}

[1] R.J.R. Skotheim (2007) Conducting PolymersTheory, Sinthesis, Properties and Characterization, CRC-Press, Teyor\& Francis Group, New York.

[2] A.G.Macdiarmid (2001) Synthetic Metals: A Novel Role for Organic Polymers (Nobel Lecture ).

[3] J.Heinze, B.Frontana-Uribe, S.Ludwigs (2010) Electrochemistry of conducting polymers--persistent models and new concepts, Chem Rev, 10, 47244771. 
[4] G.Wallace, G.Spinks, M.Kane-Meguire, A.Leon, P. Teasdale (2009) Conductive Electroactive Polymers, 3rd. Teyor\& Francis Group, Boca Raton, London, New York.

[5] J.Kankare (1998) Conducting polymers: Basic Methods of Synthesis and Characterization, book Electrical and Optical Polymer Systems: Fundamentals, Methods and Applications, CRC Press New York, p. 167-199.

[6] Inzlet, Conducting Polymers-A New Era in Eelctrochemistry (2008) Springer-Verlag, Heidelrberg, Berlin

[7] K.M.Ziadan (2012) Conducting Polymers Application in book New Polymers for Special Applications, p. 3-24, Intech, Rijeka.

[8] A. Pron, P. Rannou (2002) Processible conjugated polymers: from organic semiconductors to organic metals and superconductors, Prog Polym Sci., 27, 135-190

[9] B.Jugović, M.Gvozdenović, J.Stevanović, T. Trišović, B.Grgur (2009) Characterization of electrochemically synthesized PANI on graphite electrode for potential use in electrochemical power sources, Mater Chem Phys,114, 939-942

[10] M.M.Gvozdenović, B.Z.Jugović, T.L.Trišović, J.S. Stevanović, B.N.Grgur, (2011) Electrochemical characterization of polyaniline electrode in ammonium citrate containing electrolyte, Mater Chem Phys, 125, 601-6059

[11] Ö.Yavuz, M.K.Ram, M.Aldissi, P.Poddar, H. Srikanth (2005) Polypyrrole composites for shielding applications, Synth Met, 151, 211-217

[12] A.Kaur, S.K.Dhawan (2012) Tuning of EMI shielding properties of polypyrrole nanoparticles with surfactant concentration, Synth Met, 162, 14711477

[13] J.D.Sudha, S.Sivakala, R. Prasanth, V.L.Reena, P. Radhakrishnan Nair (2009) Development of electromagnetic shielding materials from the conductive blends of polyaniline and polyanilineclay nanocomposite-EVA: Preparation and properties, Compos Sci Technol, 69, 358-364

[14] D.Bezbradica, B.Jugović, M.Gvozdenović, S. Jakovetić, Z.Knežević-Jugović (2011) Electrochemically synthesized polyaniline as support for lipase immobilization, J Mol Catal B Enzym, 70, 55-60

[15] B.Jugović, B.Grgur, M.Antov, Z.Knežević-Jugović, J.Stevanović, M.Gvozdenović (2016) Polypyrrolebased enzyme electrode with immobilized glucose oxidase for electrochemical determination of glucose, Int J Electrochem Sci, 11, 1152-1161

[16] M.M.Gvozdenović, B.Z.Jugović, D.I.Bezbradica, M. G.Antov, Z.D.Knežević-Jugović, and B. N. Grgur (2011) Electrochemical determination of glucose using polyaniline electrode modified by glucose oxidase, Food Chem, 124, 396-400

[17] N.Popović, B.Jugović, B. Jokić, Z. Knežević-Jugovć, J.Stevanović, B.Grgur, M.Gvozdenović (2015) Electrochemical template-free synthesis of nanofibrous polyaniline modified electrode for ascorbic acid determination, Int J Electrochem Sci, $10,1208-1220$

[18] R.Ramya, R.Sivasubramanian, M.V. Sangaranarayanan (2012) Conducting polymersbased electrochemical supercapacitors-Progress and prospects, Electrochim Acta, 101, 109-129.

[19] Y.Zhang, H.Feng, X.Wu, L.Wang, A.Zhang, T.Xia, H.Dong, X.Li, L.Zhang (2009) Progress of electrochemical capacitor electrode materials: A review, Int J Hydrogen Energy, 34, 4889-4899.

[20] N. Krstajić, B. Grgur, S. Jovanović, M. Vojinović, (1997) Corrosion protection of mild steel by polypyrrole coatings in acid sulfate solutions, Electrochim Acta, 42, 1685-1691.

[21] G.Spinks, A.Dominis, G.Wallace, D.Tallman (2002) Electroactive conducting polymers for corrosion control, J Solid State Electrochem, 2, 85-100.

[22] S.Biallozor, A.Kupniewska (2005) Conducting polymers electrodeposited on active metals,Synth Met,155, 443-449.

[23] M.Gvozdenović, B.N.Grgur (2009) Electrochemical polymerization and initial corrosion properties of polyaniline-benzoate film on aluminum, Prog Org Coatings, 65, 401-404.

[24] A.R.Elkais, M.M.Gvozdenović, B.Z.Jugović, B. N.Grgur (2013) The influence of thin benzoatedoped polyaniline coatings on corrosion protection of mild steel in different environments, Prog Org Coatings, 76, 670-676.

[25] B.N.Grgur, P.Živković, M.M.Gvozdenović (2006) Kinetics of the mild steel corrosion protection by polypyrrole-oxalate coating in sulfuric acid solution, Prog Org Coatings, 56, 240-247.

[26] B. N. Grgur, A. R. Elkais, M. M. Gvozdenović, S. Ž. Drmanić, T. L.Trišović, B. Z. Jugović (2015) Corrosion of mild steel with composite polyaniline coatings using different formulations, Prog Org Coatings, 79, 17-24.

[27] M.M.Popović, B.N.Grgur, V.B.Mišković-Stanković (2005) Corrosion studies on electrochemically deposited PANI and PANI/epoxy coatings on mild steel in acid sulfate solution, Prog Org Coatings, 52, 359-365.

[28] B.N.Grgur, M.M.Gvozdenović, V.B.MiškovićStanković, Z.Kačarević-Popović (2006) Corrosion behavior and thermal stability of electrodeposited PANI/epoxy coating system on mild steel in sodium chloride solution, Prog Org Coatings, 56, 214-219.

[29] M.M.Popović, B.N.Grgur (2004) Electrochemical synthesis and corrosion behavior of thin polyanilinebenzoate film on mild steel, Synth Met, 143, 191195.

[30] T.S.Radoman, J.V.Džunuzović, B.N.Grgur, M.M. Gvozdenović, B.Z.Jugović, D.S.Miličević, E.S. Džunuzović (2016) Improvement of the epoxy coating properties by incorporation of polyaniline surface treated $\mathrm{TiO} 2$ nanoparticles previously modified with vitamin B6, Prog Org Coatings, 99, 346-355.

[31] J.Stejskal, P.Kratochvíl, A.Jenkins, I.Sapurina (1996) The formation of polyaniline and the nature of its structures, Polymer (Guildf), 37,1420-1481. 
[32] N. Gospodinova, L. Terlemezyan (1998) Conducting polymers prepared by oxidative polymerization: polyaniline, Prog Polym Sci 23,1443-1484.

[33] P.Fedorko, M.Trznadel, A.Pron, D.Djurado, J. Planès, J.P.Travers (2010) New analytical approach to the insulator-metal transition in conductive polyaniline, Synth Met, 160,1668-1671.

[34] S. Jovanović, G. Nestorović, K. Jeremić (2003) Elektroporovodni polimerni materijali, Hem Ind, 57, 511-525.

[35] M.M.Gvozdenović, B.Z.Jugović, J.S.Stevanović, B.N.Grgur (2014) Electrochemical synthesis of electroconducting polymers, Hem Ind, 68, 673-684.

[36] M.M.Gvozdenović, B.N.Grgur (2009) Electrochemical polymerization and initial corrosion properties of polyaniline-benzoate film on aluminum, Prog Org Coatings, 65, 401-404.

[37] M.M.Gvozdenović, B.Z.Jugović, J.S.Stevanović, B. Grgur, T.LJ.Trišović, Z.S.Jugović (2011) Electrochemical synthesis and corrosion behavior of polyaniline-benzoate coating on copper, Synth Met, 161, 1313-1317.

[38] J. Petitjean, S. Aeiyach, J. Lacroix, P.Lacaze (1999) Ultra-fast electropolymerization of pyrrole in aqueous media on oxidizable metals in a one-step process, J Electroanal Chem, 478, 92-100.

[39] J. L. Camalet, J.C.Lacroix, S. Aeiyach, P.C.Lacaze (1998) Characterization of polyaniline films electrodeposited on mild steel in aqueous $p$ toluenesulfonic acid solution, Synth Met, 445, 117124.

[40] U.Riaz, C.Nwaoha, S.M.Ashraf (2014) Recent advances in corrosion protective composite coatings based on conducting polymers and natural resource derived polymers, Prog Org Coatings, 77, 743-756.

[41] S.Sathiyanarayanan, S.Muthukrishnan, G. Venkatachari, D.C.Trivedi (2005) Corrosion protection of steel by polyaniline (PANI) pigmented paint coating, Prog. Org. Coatings, 53(4), 297-301.

[42] E. Armelin, Á. Meneguzzi, C. A. Ferreira, C. Alemán (2009) Polyaniline, polypyrrole and poly(3,4ethylenedioxythiophene) as additives of organic coatings to prevent corrosion, Surf Coatings , 203, 3763-3769.

[43] R.Rathnayake, M.Mantilaka, M.Hara, H.H.Huang, H. Wijayasinghe, M. Yoshimura, H. Pitawala (2017) Graphite intercalated polyaniline composite with superior anticorrosive and hydrophobic properties, as protective coating material on steel surfaces, Appl Surf Sci, 410, 445-453.

[44] L.S.Shtykova, D.Ostrovskii, P.Handa, K.Holmberg, M. Nydén (2004) NMR diffusometry and FTIR in the study of the interaction between antifouling agent and binder in marine paints, Prog Org Coatings, 51 , 125-133.

[45] B.A.Bhanvase, S.H.Sonawane (2010) New approach for simultaneous enhancement of anticorrosive and mechanical properties of coatings: Application of water repellent nano CaCO3-PANI emulsion nanocomposite in alkyd resin, Chem Eng J, 156, 177-183.
[46] J.Alam, U.Riaz, S.Ahmad (2009) High performance corrosion resistant polyaniline/alkyd ecofriendly coatings, Curr Appl Phys, 9, 80-86.

[47] J.Alam, U.Riaz, S.M.Ashraf, S.Ahmad (2008) Corrosion-protective performance of nano polyaniline/ferrite dispersed alkyd coatings, J Coatings Technol Res, 5, 123-128.

[48] G.S.Gonalves, A.F.Baldissera, L.F.Rodrigues, E. M. A.Martini, C.A.Ferreira (2011) Alkyd coatings containing polyanilines for corrosion protection of mild steel, Synth Met, 161, 313-323.

[49] M.Martí, G.Fabregat, D.S.Azambuja, C.Alemán, E. Armelin (2012) Evaluation of an environmentally friendly anticorrosive pigment for alkyd primer, Prog Org Coatings, 73, 321-329.

[50] S.Bhadra, D.Khastgir, N.K.Singha, J.H.Lee (2009) Progress in preparation processing and applications of polyaniline, Prog Polym, Sci, 34, 783-810.

[51] H.G.Taleghani, M.Aleahmad, H.Eisazadeh (2011) Preparation and Characterization of Polyaniline Nanoparticles Using Various Solutions, World Applied Sciences Journal, 6, 1607-1611.

[52] A.Kalendová, D.Veselý, J.Stejskal (2008) Organic coatings containing polyaniline and inorganic pigments as corrosion inhibitors, Prog Org Coatings, 62, 105-116.

[53] S.Sathiyanarayanan, S.Syed Azim, G. Venkatachari (2009) Corrosion protection coating containing polyaniline glass flake composite for steel, Electrochim Acta, 53, 2087-2094.

[54] G.Gupta, N.Birbilis, A.B.Cook, A.S.Khanna (2013) Polyaniline-lignosulfonate/epoxy coating for corrosion protection of AA2024-T3, Corros Sci, 67, 256-267.

[55] E. Armelin, R. Pla, F. Liesa, X. Ramis, J. I. Iribarren, C.Alemán (2008) Corrosion protection with polyaniline and polypyrrole as anticorrosive additives for epoxy paint, Corros Sci, 50, 721-728.

[56] C. Y. Ge, X. G. Yang, B. R. Hou (2012) Synthesis of polyaniline nanofiber and anticorrosion property of polyaniline-epoxy composite coating for Q235 steel, J Coatings Technol Res, 9, 59-69.

[57] A. Mostafaei, F. Nasirpouri (2014) Epoxy/polyaniline -ZnO nanorods hybrid nanocomposite coatings: Synthesis, characterization and corrosion protection performance of conducting paints, Prog Org Coatings, 77, 146-159.

[58] C.H.Chang, T.C.Huang, C.W.Peng, T.C.Yeh, H.I. Lu, W. I.Hung, C.J.Weng, T.I.Yang, J.M.Yeh (2012) Novel anticorrosion coatings prepared from polyaniline/graphene composites, Carbon, 50, 5044-5051.

[59] K. A.Thomas, S.Nair, R.Rajeswari, A.V.Ramesh Kumar, V.Natarajan, T.Mukundan, R.John (2015) Electrochemical behaviour of PANi/polyurethane antifouling coating in salt water studied by electrochemical impedance spectroscopy, Prog Org Coatings, 89, 267-270.

[60] R.Ansari, A.H.Alikhani (2009) Application of polyaniline/nylon composites coating for corrosion protection of steel, J Coatings Technol Res, 6, 221227. 
[61] J. Li, L. Ecco, M. Fedel, V. Ermini, G. Delmas, J. Pan (2015) In-situ AFM and EIS study of a solventborne alkyd coating with nanoclay for corrosion protection of carbon steel, Prog Org Coatings, 87, 179-188.

[62] S.Sathiyanarayanan, S.S.Azim, G.Venkatachari (2007) A new corrosion protection coating with polyaniline-TiO2composite for steel, Electrochim Acta, 52, 2068-2074.

[63] G.Ćirić-Marjanović (2013) Recent advances in polyaniline research: Polymerization mechanisms, structural aspects, properties and applications," Synth Met, 177, 1-47.

[64] D.E.Tallman, G.Spinks, A.Dominis, G.Wallace (2002) Electroactive conducting polymers for corrosion control, J Solid State Electrtochem, 6, 7384.

[65] J.Stejskal, I.Sapurina, M.Trchová (2010) Polyaniline nanostructures and the role of aniline oligomers in their formation, Prog Polym Sci, 35, 1420-1481.

[66] J.Stejskal, I.Sapurina (2005) Polyaniline: Thin films and colloidal dispersions (IUPAC Technical Report), Pure Appl Chem, 77, 815-826.

[67] E.M.Geniès, A.Boyle, M.Lapkowski, C.Tsintavis (1990) Polyaniline: A historical survey, Synth Met, 36, 139-182.
[68] B. Einar (2004) Corrosion and Protection, SpringerVerlag, London

[69] F.Amy (2006) Corrosion Control Trough Organic Coatings, Teyor\& Francis Group, Boca Raton, London, New York

[70] S.Radhakrishnan, N.Sonawane, C.R.Siju (2001) Epoxy powder coatings containing polyaniline for enhanced corrosion protection, Prog. Org. Coatings, 64(4), 383-386, 2009.

[71] A.F.Baldissera, C.A.Ferreira (2012) Coatings based on electronic conducting polymers for corrosion protection of metals, Prog Org Coatings, 75, 241-247.

[72] Y. T. Lin, T. M. Don, C. J. Wong, F. C. Meng, Y. J. Lin, S.Y.Lee, C.F.Lee, W.Y.Chiu (2018) Improvement of mechanical properties and anticorrosion performance of epoxy coatings by the introduction of polyaniline/graphene composite, Surf. Coatings Tech, in press

[73] A.R.Elkais, M.M.Gvozdenović, B.Z.Jugović, J.S. Stevanović, N.D.Nikolić, B.N.Grgur (2011) Electrochemical synthesis and characterization of polyaniline thin film and polyaniline powder,Prog. Org. Coatings, 71, 32-35.

\title{
IZVOD
}

\section{PRIMENA POLIANILINA KAO INHIBITORA KOROZIJE KLASIČNIH ORGANSKIH PREVLAKA}

\begin{abstract}
Primena sistema klasičnih organskih prevlaka za zaštitu metala i legura od korozije je najrasprostranjeniji vid zašte. Primena inhibitora korozije na bazi polianilina (PANI) je zasnovana na njegovom eksperimentalno potvrđenom zaštitnom dejstvu. Osnovni motiv za primenu PANI je zamena ekološki neprihvatljivih materijala koji se korite kao inhibitori. Eksperimentalna istraživanja u ovoj oblsti bazirana su na proučavanju fizičkih svojstava prevlaka primenom spektoskopskih tehnika: FTIR, Ramanske spektroskopije i UV spektroskopije, termogravimetrijske analize, SEM i TEM mikroskopija, dok se ispitivanja zaštitnih svojstava prevlaka na baziraju na ubrzanim korozionim testovima primenom slane i vlažne komore, eksperimentima spektroskopije elektrohemijske impedancije i polarizacionim merenjima.
\end{abstract}

Ključne reči: polianilin, inhibitori, epoksidne prevlake, alkidne prevlake.

Pregledni rad

Rad primljen: 26. 04. 2018.

Rad prihvaćen: 13. 05. 2018.

Rad je dostupan na sajtu: www.idk.org.rs/casopis

(c) 2018 Authors. Published by Engineering Society for Corrosion. This article is an open access article distributed under the terms and conditions of the Creative Commons Attribution 4.0 International license (https://creativecommons.org/licenses/by/4.0/) 